\title{
To Dab or Not to Dab: Rising Concerns Regarding the Toxicity of Cannabis Concentrates
}

\author{
Saeed K. Alzghari ${ }^{1}$, Victor Fung ${ }^{2}$, Shannon S. Rickner ${ }^{3}$, Liza Chacko $^{4}$, Steven W. Fleming ${ }^{4}$ \\ 1. Gulfstream Genomics, Gulfstream Diagnostics 2. Department of Emergency Medicine, Parkland Health \\ and Hospital System, Dallas Texas 3. Department of Emergency Medicine, UT Southwestern Medical \\ Center 4. Reference Health Laboratories, Gulfstream Diagnostics
}

$\square$ Corresponding author: Steven W. Fleming, sfleming@gulfdiagnostics.com Disclosures can be found in Additional Information at the end of the article

\section{Abstract}

Cannabis use is steadily rising in the United States. As the popularity of marijuana rises, new varieties of cannabis-related products are becoming available. Dabs are cannabis concentrates gaining notoriety for their significant amounts of tetrahydrocannabinol (THC) that are ultimately vaporized and inhaled for their effect. Herein, we provide an overview of recent cases of dabbing to bring awareness to the clinicians, of the significant adverse effects associated with dabs including psychosis, neurotoxicity, and cardiotoxicity.

Categories: Emergency Medicine, Epidemiology/Public Health

Keywords: marijuana, dabs, dabbing, cardiotoxicity, psychosis, neurotoxicity, cannabis, cannabis concentrates

Received 08/25/2017

Review began 09/05/2017

Review ended 09/07/2017

Published 09/11/2017

C) Copyright 2017

Alzghari et al. This is an open access article distributed under the terms of the Creative Commons Attribution License CC-BY 3.0., which permits unrestricted use, distribution, and reproduction in any medium, provided the original author and source are credited.

\section{Editorial}

The popularity of cannabis has been growing in recent decades. Among adults in the United States, this rise in the use of cannabis can be attributed to more states deciding to legalize marijuana [1]. Currently, 29 states have legalized medical marijuana, eight of these states have recreational marijuana laws and likely, both numbers will continue to rise [2].

Since the number of people using cannabis for recreational purposes is increasing, there are varieties of cannabis preparations that are becoming more available to the public. Some of the varieties of cannabis concentrates include "oil," "budder," "crumble," "wax," and "dabs” that are typically created by taking Butane solvent and extracting the cannabinoid for a more potent product [3]. A method of consumption that is gaining notoriety is dabbing. Dabbing is defined as "a new method of consumption of cannabis whereby a cannabis concentrate is volatilized via application to a hot platform and the vapor is subsequently passed through a water pipe device and inhaled by the end user" [3]. The two main compounds typically found in dabs are cannabidiol (CBD) and tetrahydrocannabinol (THC) (Figure 1). Recently published case reports have shown significant psychosis, neurotoxicity, and cardiotoxicity associated with dabs [4-5]. In these three cases presented, each subject was a male in their teens or twenties and used some form of dab via inhalation (Table 1). None of the cases reported the amount or the dose of the dabs taken leading to toxicity. Two of the subjects presented with paranoia-like symptoms and one subject presented with seizure-like activity. Two of the subjects reported marked hypertension along with fever upon presentation. One case noted elevated troponins signifying cardiotoxicity in the form of myocardial injury [4]. The treatment using a benzodiazepine occurred in two cases. Furthermore, the treatment using an antipsychotic occurred in two of 


\section{Cureus}

the cases. Of note, Rickner and colleagues analyzed the dab sample which the patient was using by mass spectrometry, revealed that the level of THC was $20.5 \%$ by weight and without any detectable level of cannabidiol (CBD) [4].

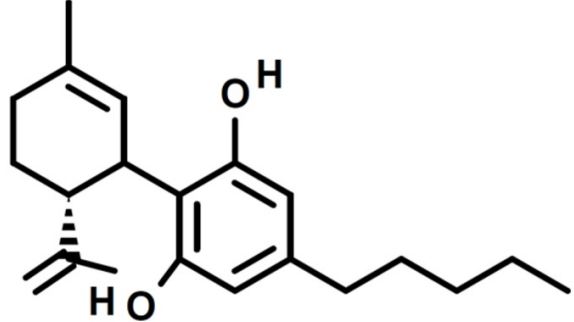

Cannabidiol

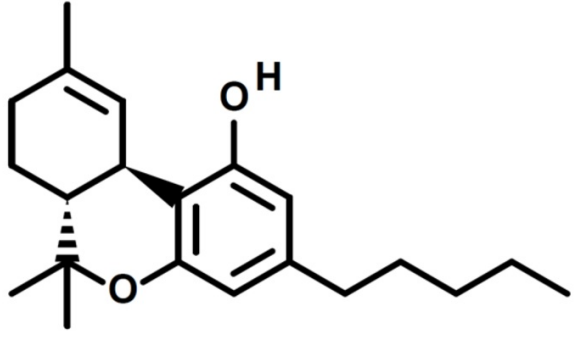

Delta-9-tetrahydrocannabinol (THC)

\section{FIGURE 1: Structures of cannabidiol and delta-nine- tetrahydrocannabinol (THC).}

\begin{tabular}{|c|c|c|c|c|c|c|c|c|c|}
\hline Author & Date & Country & $\begin{array}{l}\text { Age } \\
\text { (Years) }\end{array}$ & Sex & Drug(s) & Route & $\begin{array}{l}\text { Urine } \\
\text { THC } \\
\text { Level }\end{array}$ & Presentation & Treatment and Outcome \\
\hline $\begin{array}{l}\text { ickne, } \\
\text { al. }\end{array}$ & $\begin{array}{l}\text { June } \\
2017\end{array}$ & USA & 17 & M & $\begin{array}{l}\text { Dabs; e- } \\
\text { cigarette }\end{array}$ & Inhalation & $\begin{array}{l}\text { carboxy- } \\
\text { THC: } 108 \\
\mathrm{ng} / \mathrm{mL} \\
\text { (detection } \\
\text { limit } 15 \\
\mathrm{ng} / \mathrm{mL} \text { ) }\end{array}$ & $\begin{array}{l}\text { Seizure-like activity; } \\
\text { alert but agitated; } \\
\text { hyperthermic; } \\
\text { hypertensive with } \\
\text { systolic blood } \\
\text { pressures in the 190s; } \\
\text { twitches and jerks of } \\
\text { his extremities; } \\
\text { elevated troponins; } \\
\text { liquid } \\
\text { chromatography- } \\
\text { mass spectrometry } \\
\text { (LCMS) of dab } \\
\text { sample contained } \\
\text { THC at } 20.5 \% \\
\text { and cannabidiol } \\
\text { (CBD) was } \\
\text { undetectable }\end{array}$ & $\begin{array}{l}\text { Received propofol infusion } \\
\text { ( } 75 \mathrm{mcg} / \mathrm{kg} / \mathrm{min} \text { ) followed by } \\
\text { midazolam }(2.5 \mathrm{mg} / \mathrm{h} \text { ) and } \\
\text { fentanyl }(125 \mathrm{mcg} / \mathrm{h}) \text { for } \\
\text { sedation; patient discharged } \\
\text { without neurologic sequelae } \\
\text { after five-day hospital stay }\end{array}$ \\
\hline $\begin{array}{l}\text { ere, } \\
\text { al. }\end{array}$ & $\begin{array}{l}\text { Feb } \\
2016\end{array}$ & USA & 17 & M & $\begin{array}{l}\text { Recreational } \\
\text { cannabis; } \\
\text { cannabis }\end{array}$ & Inhalation & N/A & $\begin{array}{l}\text { Over the course of } \\
\text { three weeks after } \\
\text { using cannabis wax, } \\
\text { experienced } \\
\text { paranoia; appeared } \\
\text { confused, } \\
\text { disorganized, and } \\
\text { agitated; mild fever; }\end{array}$ & $\begin{array}{l}\text { Received risperidone } 3 \\
\mathrm{mg} / \text { day over one week where } \\
\text { he returned to baseline mental } \\
\text { status after } 12 \text {-day hospital }\end{array}$ \\
\hline
\end{tabular}




\section{Cureus}

\begin{tabular}{|c|c|c|c|c|c|c|c|c|c|}
\hline & & & & & wax & & & $\begin{array}{l}\text { tachycardia (up to } 110 \\
\text { beats/minute); } \\
\text { hypertension (up to } \\
\text { 170/90 } \mathrm{mmHg} \text { ); } \\
\text { diaphoresis; } \\
\text { photophobia }\end{array}$ & stay \\
\hline $\begin{array}{l}\text { Pierre, } \\
\text { et al. } \\
{[5]}\end{array}$ & $\begin{array}{l}\text { Feb } \\
2016\end{array}$ & USA & 26 & M & $\begin{array}{l}\text { Medical } \\
\text { marijuana; } \\
\text { cannabis } \\
\text { wax (“Fire } \\
\text { OG" and } \\
\text { "Mystery") }\end{array}$ & Inhalation & N/A & $\begin{array}{l}\text { Over the course of } 18 \\
\text { months, the patient } \\
\text { became increasingly } \\
\text { restless, confused, } \\
\text { and disorganized; } \\
\text { signs of paranoia }\end{array}$ & $\begin{array}{l}\text { Treated with olanzapine } 20 \\
\mathrm{mg} / \text { day on HD one, } \\
\text { transitioned to risperidone } 2 \\
\mathrm{mg} / \text { day on HD two, } \\
\text { risperidone discontinued on } \\
\mathrm{HD} \text { three with little } \\
\text { improvement; by HD seven } \\
\text { and eight, patient experienced } \\
\text { catatonia resulting in initiation } \\
\text { of lorazepam } 2 \text { mg three times } \\
\text { per day(TID) that resulted in } \\
\text { resolution of catatonia } \\
\text { followed by restarting } \\
\text { risperidone } 4 \text { mg/day; } \\
\text { discharged after } 17 \text {-day } \\
\text { hospital stay }\end{array}$ \\
\hline
\end{tabular}

\section{TABLE 1: Recent case reports involving the use of "dabs" and their outcomes.}

Abbreviations: h: hour, HD: hospital day, kg: kilograms, LCMS: liquid chromatography-mass spectrometry, mcg: micrograms, mg: milligrams, $\mathrm{mmHg}$ : millimeters of mercury, $\mathrm{ng} / \mathrm{mL}$ : nanograms per milliliter, THC: tetrahydrocannabinol, TID: three times per day.

Dabs that are homemade or obtained from an unreliable source may be prone to containing residual solvent (i.e. Butane, pesticides, or other contaminants). Raber and colleagues performed a study analyzing 57 samples of cannabis concentrates for contaminants and found that over $80 \%$ of the samples were contaminated by solvents or pesticides in some form [3]. Another interesting finding was that 56 out of the 57 samples had maximum THC concentrations ranging from $23.7 \%$ to $75.9 \%$. One could argue that contaminants might play a role in the toxicity experienced in the cases presented; however, the dab sample analyzed by Rickner and colleagues revealed that concentrated levels of THC might play a bigger role in regard to toxicity [4]. There is a need for more research on the toxic dose of THC in humans in order to guide the clinicians in treating the patients experiencing adverse effects associated with dabs and other cannabis-related products.

In conclusion, medical providers need to be more aware of the dangers of dabbing. Dabs can have varying levels of contaminants, THC and CBD levels that could potentially trigger a toxidrome leading to psychosis, neurotoxicity, or cardiotoxicity. We advocate for more research into how the concentration of THC in dabs can lead to such adverse effects.

\section{Additional Information}

\section{Disclosures}

Conflicts of interest: In compliance with the ICMJE uniform disclosure form, all authors 
declare the following: Payment/services info: All authors have declared that no financial support was received from any organization for the submitted work. Financial relationships: Saeed K. Alzghari, Liza Chacko, and Steven W. Fleming declare(s) employment from Gulfstream Diagnostics. Other relationships: All authors have declared that there are no other relationships or activities that could appear to have influenced the submitted work.

\section{References}

1. Hasin DS, Sarvet AL, Cerdá M, et al.: US adult illicit cannabis use, cannabis use disorder, and medical marijuana laws: 1991-1992 to 2012-2013. JAMA Psychiatry. 2017, 74:579-588. 10.1001/jamapsychiatry.2017.0724

2. Carliner H, Brown QL, Sarvet AL, et al.: Cannabis use, attitudes, and legal status in the U.S: A review. Prev Med. 2017, 10.1016/j.ypmed.2017.07.008

3. Raber JC, Elzinga S, Kaplan C: Understanding dabs: contamination concerns of cannabis concentrates and cannabinoid transfer during the act of dabbing. J Toxicol Sci. 2015, 40:797803. 10.2131/jts.40.797

4. Rickner SS, Cao D, Kleinschmidt K, et al.: A little "dab" will do ya': a case report of neuro-and cardiotoxicity following use of cannabis concentrates. Clin Toxicol. 2017, 55:1011-1013. 10.1080/15563650.2017.1334914

5. Pierre JM, Gandal M, Son M: Cannabis-induced psychosis associated with high potency "wax dabs". Schizophr Res. 2016, 172:211-212. 10.1016/j.schres.2016.01.056 